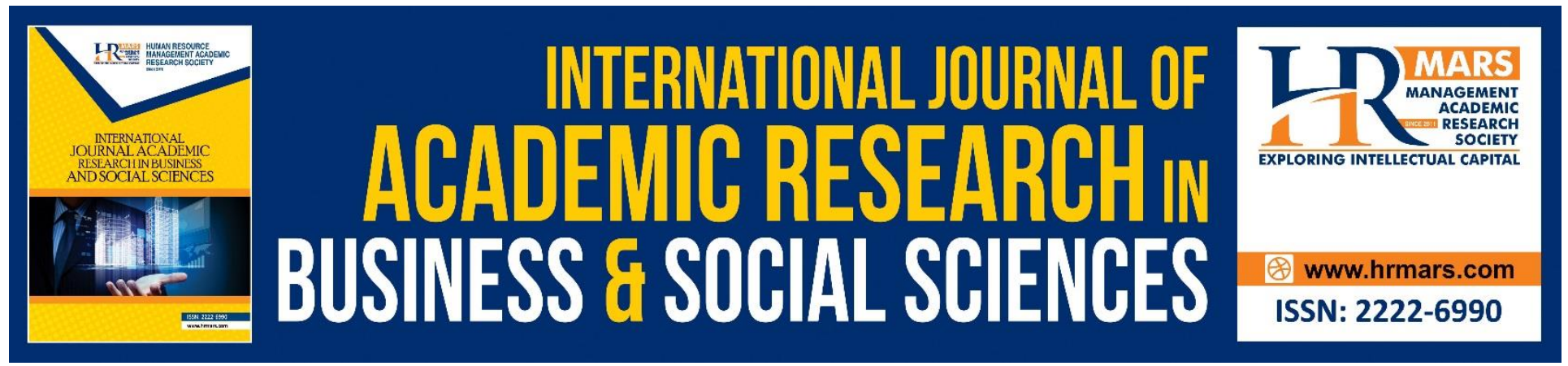

\title{
The Competitive Advantage of Technology: The Impact of Human Resources, Organization and Technology at a Local State Government-Based Organization
}

Shamsul Azren Mohd Shukor, Zarina Abdul Munir, Muhammad Aliff Ibrahim, Norhayati Omar, Shaherah Abdul Malik

To Link this Article: http://dx.doi.org/10.6007/IJARBSS/v9-i6/6067

DOI: $10.6007 /$ IJARBSS/v9-i6/6067

Received: 12 April 2019, Revised: 18 May 2019, Accepted: 05 June 2019

Published Online: 27 June 2019

In-Text Citation: (Shukor, Munir, Ibrahim, Omar, \& Malik, 2019)

To Cite this Article: Shukor, S. A. M., Munir, Z. A., Ibrahim, M. A., Omar, N., \& Malik, S. A. (2019). The Competitive Advantage of Technology: The Impact of Human Resources, Organization and Technology at a Local State Government-Based Organization. International Journal of Academic Research in Business and Social Sciences, 9(6), 1061-1070.

Copyright: (C) 2019 The Author(s)

Published by Human Resource Management Academic Research Society (www.hrmars.com)

This article is published under the Creative Commons Attribution (CC BY 4.0) license. Anyone may reproduce, distribute, translate and create derivative works of this article (for both commercial and non-commercial purposes), subject to full attribution to the original publication and authors. The full terms of this license may be seen

at: http://creativecommons.org/licences/by/4.0/legalcode

Vol. 9, No. 6, 2019, Pg. $1061-1070$

http://hrmars.com/index.php/pages/detail/IJARBSS

JOURNAL HOMEPAGE

Full Terms \& Conditions of access and use can be found at http://hrmars.com/index.php/pages/detail/publication-ethics 


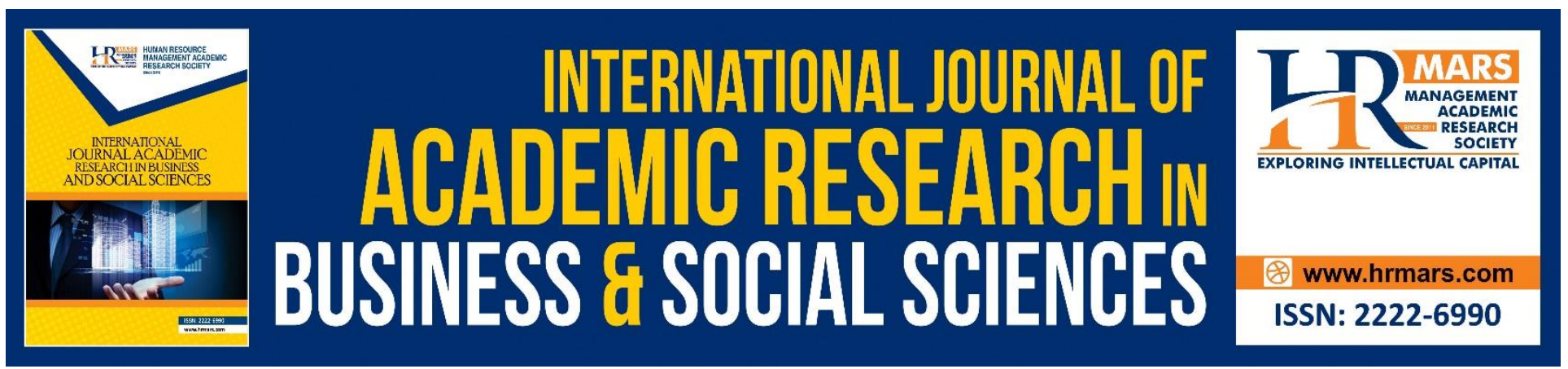

\title{
The Competitive Advantage of Technology: The Impact of Human Resources, Organization and Technology at a Local State Government-Based Organization
}

\section{Shamsul Azren Mohd Shukor, Zarina Abdul Munir, Muhammad Aliff Ibrahim, Norhayati Omar}

Faculty of Business and Management, Universiti Teknologi MARA, Puncak Alam,Malaysia

\author{
Shaherah Abdul Malik \\ Faculty of Business and Management, Universiti Teknologi MARA, Johor,Malaysia \\ Email: sshukor2001@yahoo.com, alifadam1973@gmail.com, aliffibrahim1995@yahoo.com, \\ norha981@puncaklam.uitm.edu.my, shahe314@johor.uitm.edu.my
}

\begin{abstract}
This paper examines the connection between information technology (IT) and employee performance as well as effectiveness. Despite indications of progress, current literature related to IT is still deficient in terms of empirical findings or a consolidation of these results. Much of research is dependent on anecdotes and case studies. The findings indicate that IT as an individual factor does not contribute to sustained performance-based advantage for an organization. However, some companies have found success in leveraging commercial and business resources along with IT elements. This paper investigates work performance and effectiveness in a state government-based organization in Malaysia. The combination of independent variables used are organization and technology, human resources and information technology, and technology and information technology.
\end{abstract}

Keywords: Competitive Advantage, Information Technology, Human Resource, Organization, Employee Performance

\section{Introduction}

Information technology (IT) involves the use of computers and other digital devices, programs and frameworks in order to organize, manage, retain and exchange electronic data. IT is usually employed in the context of activities carried out on an individual basis or for leisure purposes. The commercial 
function of IT incorporates telephony as well as computer innovation. The term data innovation is credited to the Harvard Trade Survey. It is used to make a distinction between devices intentionally built to carry out a specific and limited range of functions, as opposed to a more general computing device which can perform multiple functions as needed. The growth of the IT industry since the middle of the $20^{\text {th }}$ century has encompassed the inclusion of coordinates circuits and transistors. This has led to a reduction in vitality utilization but an increase in computing functionality. This pattern repeats when new innovations arise.

\section{Literature Review}

This chapter offers an overview of existing literature related to this subject. The established independent variables for this study are the combinations of human resources and IT, organization and IT, and technology and IT. These factors can influence employee performance and effectiveness, and as such a selection of journals which provide insight into this topic were examined.

Employee Performance and Effectiveness

According to Litwin (2011) the connection between employee involvement (EI) and organizational execution is ambiguous, and this is made more complex by the manner in which information technology (IT) is spread across the workplace. It is asserted that modern developments in technology can provide a vital avenue through which El can boost organizational execution. It is also argued that those who take El into account in the context of mechanical changes may be focusing only on workplace-level indicators of work relationships and ignoring the more varied strategy-based approaches in fostering work connection.

Kiruja (2013) asserts that the performance level of representatives dictates an organization's success in reaching its crucial targets. Representative execution relies on inspiration and capacity. In this context inspiration is the internal motivation which leads to actions, while capacity is the capability, preparation and resources required to fulfill a task. Less bureaucracy and a strong labour association presence are also encouraged to guarantee a solid foundation for employees and organizational administration.

Combination of Human Resources With It

The human resources department is one of the most vital components of any organization worldwide. The decisions made by Human Resources Management (HRM) can have wide-reaching and varied impacts. Gerhart (1996) asserts that a continuously evolving market and changing client demands all influence HRM choices. This consequently impacts viability and employee execution. An organization's HR framework is a vital resource in the performance of employees and the firm as a whole. Vital resources are defined as resources that are difficult to trade, replicate or obtain, and perform specific functions that contribute to the organization's competitive edge. Unlike capital or finances, a strong HR framework is not a prominent or obvious asset, but is deeply ingrained into the structure of the firm and allows for its smooth functioning and enhanced performance. This aligns with Prahalad and Hamel's (1990) concept of "center competencies", which is reflected in usual methods of financial rents and the capacity for "center competence-people-embodied" perspectives. Combination of Organization With Information Technology (It)

Computers have outgrown their capabilities since the days of the Check I machine in 1939, which was the precursor to modern day computers, as well as the ENIAC in 1943, which was the first computing 
machine with no movable parts. Computers influence commercial trade and the financial world in significant ways. Erik Brynjolfsson and Lorin M. Hitt (2000) explain that as computers became more efficient and affordable, the trade esteem of computers is dictated less by computational features and more by the of strategies, programs and structures that enhance existing capabilities. The continuing growth of technology will ensure that computing processes and programs will further evolve and improve over time.

Combination of Technology with Information Technology (It)

According to Unesco (2002) innovation sustains commercial exchanges, boosts the success rates of modern firms and provides a solid framework for governments. Concurrently, innovation also adds esteem to the process of real-time learning within organizations. The internet can be a strong motivator for the growth and benefit of the company. An organization should be capable of taking advantage of technological developments. In order to achieve this, the company must ensure that a selection of experts is trained in strong ICT fundamentals. Innovative modifications to the work environment can influence the performance of employees and the organization as a whole. Several forms of competencies are becoming more relevant in this context, namely ICT competencies, decision-making processes, the capacity to work in groups, efficient communication and general or basic competencies.

\section{Research Framework}

Independent Variable $\quad$ Dependent Variable

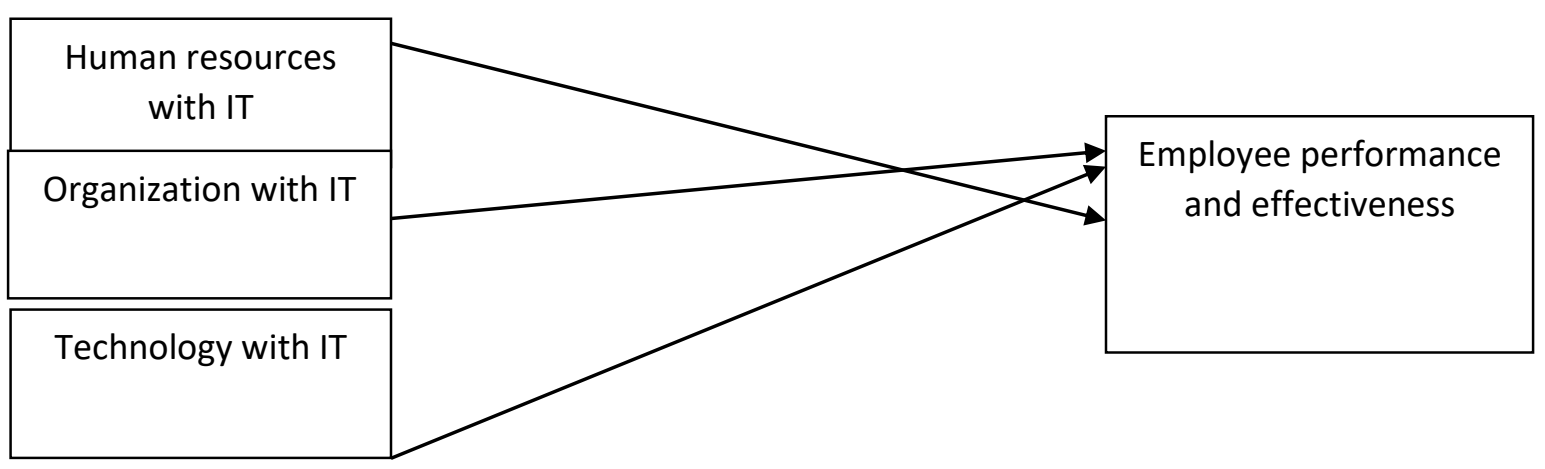

The figure above details how the independent and dependent variables are connected to the research topic. Information technology is an element which allows for more competitive benefits when paired with the important roles played by human resources, the organization, and technology. The three independent variables for this study are the combination of human resources with IT, the combination of organization with IT, and the combination of technology with IT.

\section{Methodology}

The objective of this study is to investigate the influence of information technology on employee performance and effectiveness at a local state-government based organization. Elements including technology, organization and human resources will also be examined in order to establish the most beneficial combination with information technology. The current study employed correlational 
analysis, with the use of a cross-sectional survey format in order to establish the extent to which employee performance and effectiveness are contingent upon the combinations of information technology with organization, human resources and technology. The correlational design was selected for this research context because all respondents were already assigned to particular shifts as part of their jobs. This study was conducted in a non-contrived manner whereby all daily work activities carried on as usual.

Data collection involves gathering and assessing information based on the established variables. The current study utilized simple random sampling which offered all employees the opportunity to be chosen as a research participant. The questionnaire was checked by a lecturer and approved for distribution to respondents. The questionnaire was prepared in two languages which will be easily understood as they are printed in both Bahasa Malaysia and English. The questionnaire method is considered suitable due to its efficiency in collecting data from a large group of respondents. Sources for the construction of the questionnaire include (Kum, Cowden, \& Karodia, 2014), (UNESCO and UNESCO Institute of for Statistics and group Talal Abu-Ghazaleh, 2013), (Smith, 2008), (Byrd \& Turner, 2000), (Bulmash, 2013), (Ahmadi, Keshavarzi, \& Foroutan, 2011).

In this study, the researcher subjects the collected data to analysis through the Statistical Package for Social Science (SPSS) software. This provides a strong and precise interpretation and management of results, with a simple and user-friendly interface that significantly lessens the burden on the researcher. SPSS comes with eight features, namely Data Editor, Viewer, Draft Viewer, Pivot Table Editor, Chart Editor, and Graph board Editor, Text output Editor, Syntax Editor and Script Editor. The SPSS 2.0 software will analyze the responses from the research participants which are keyed in to the system, and calculate the various permutations and interpretations that are generated.

\section{Results and Discussion}

This chapter will outline and explain the data analysis process of the factors which impact employee performance and effectiveness at a local state government-based organization. The data was analyzed using the Statistical Package for Social Science (SPSS) software. This section elaborates on the relationships between the dependent variable (DV) and the independent variables (IV). The data collected from the questionnaire responses were subjected to frequency analysis, descriptive analysis, Pearson's correlation analysis and regression analysis. The results are illustrated in the form of tables.

Correlation analysis

Correlation and regression analysis methods were employed to examine the relationship between employee performance and effectiveness with the combinations of organization, human resources and technology with information technology (IT). The correlation coefficients of the three variables are depicted in the following table: 
INTERNATIONAL JOURNAL OF ACADEMIC RESEARCH IN BUSINESS AND SOCIAL SCIENCES Vol. 9, No. 6, June, 2019, E-ISSN: 2222-6990 @ 2019 HRMARS

\begin{tabular}{|c|c|}
\hline Correlation coefficient range & Strength of association \\
\hline \pm 0.71 to \pm 0.99 & Strong \\
\hline \pm 0.31 to \pm 0.70 & Moderate \\
\hline \pm 0.01 to \pm 0.30 & Weak \\
\hline
\end{tabular}

Pearson's correlation

Correlations

\begin{tabular}{|c|c|c|c|c|c|}
\hline & & $\mathrm{Hr} \& \mathrm{IT}$ & Org \& IT & $\begin{array}{c}\text { Tech \& } \\
\text { IT }\end{array}$ & $\begin{array}{c}\text { Employee } \\
\text { performance \& } \\
\text { effectiveness }\end{array}$ \\
\hline \multirow{5}{*}{$\begin{array}{l}\mathrm{Hr} \& \\
\text { IT }\end{array}$} & Pearson & 1 & $.671^{* *}$ & $.646^{* *}$ & $.579^{* *}$ \\
\hline & Correlation & & & & \\
\hline & Sig. (2-tailed) & & .000 & .000 & .000 \\
\hline & $\mathrm{N}$ & 100 & 100 & 100 & 100 \\
\hline & Pearson & $.671^{* *}$ & 1 & $.741^{* *}$ & $.672^{* *}$ \\
\hline \multirow{4}{*}{$\begin{array}{l}\text { Org \& } \\
\text { IT }\end{array}$} & Correlation & & & & \\
\hline & Sig. (2-tailed) & .000 & & .000 & .000 \\
\hline & $\mathrm{N}$ & 100 & 100 & 100 & 100 \\
\hline & Pearson & $.646^{* *}$ & $.741^{* *}$ & 1 & $.590^{* *}$ \\
\hline \multirow{3}{*}{$\begin{array}{l}\text { Tech } \\
\& I T\end{array}$} & Correlation & & & & \\
\hline & Sig. (2-tailed) & .000 & .000 & & .000 \\
\hline & $\mathrm{N}$ & 100 & 100 & 100 & 100 \\
\hline \multirow{3}{*}{$\begin{array}{l}\text { Empl } \\
\text { oyee } \\
\text { perf } \\
\& \\
\text { effect } \\
\text { ivene } \\
\text { ss }\end{array}$} & $\begin{array}{l}\text { Pearson } \\
\text { Correlation }\end{array}$ & $.579^{* *}$ & $.672^{* *}$ & $.590^{* *}$ & 1 \\
\hline & Sig. (2-tailed) & .000 & .000 & .000 & \\
\hline & $\mathrm{N}$ & 100 & 100 & 100 & 100 \\
\hline
\end{tabular}

**. Correlation is significant at the 0.01 level (2-tailed).

The data analysis reveals the correlation between the independent variables and dependent variable. The table above establishes that the Pearson's correlation coefficient between employee performance and effectiveness with human resources and information technology is 0.579 which is significant at 0.00 levels. Since the P-value is less than 0.01 , the relationship between these two variables is considered significant. The correlation degree between employee performance and the combination of human resources and information technology is moderate. The second correlation is between employee performance and effectiveness with combination of organization with information technology. The Pearson correlation coefficient between this combination of independent variable and dependent variable is 0.672 significant at 0.00 levels. The relationship between these two variables is significant, while the correlation between the two variables is 
INTERNATIONAL JOURNAL OF ACADEMIC RESEARCH IN BUSINESS AND SOCIAL SCIENCES Vol. 9, No. 6, June, 2019, E-ISSN: 2222-6990 @ 2019 HRMARS

moderate. The last Pearson correlation coefficient is that of the last independent variable, namely the combination of technology with information technology and employee performance and effectiveness, where the correlation value is 0.590 . The relationship between these two variables is significant. The correlation between the two variables is moderate.

\section{Regression Analysis}

\section{Model Summary}

\begin{tabular}{|l|l|l|l|l|l|}
\hline Model & R & R Square & $\begin{array}{l}\text { Adjusted } \\
\text { Square }\end{array}$ & $\begin{array}{l}\text { Std. Error of } \\
\text { the Estimate }\end{array}$ \\
\hline 1 & $.700^{\mathrm{a}}$ & .490 & .474 & .31654 \\
\hline
\end{tabular}

a. Predictors: (Constant), IV3, iv1, IV2

The above table details that the $\mathrm{F}$ values are 30.685 and it is significant at 0.00 . It establishes that the model is statistically significant and qualifies as reliable for the regression analysis. The value of $R^{2}$ is 0.490 , which indicates that $49.0 \%$ of the variance is the factor that impacts employee performance and effectiveness (dependent variable) and it is explained by the combination of human resources, organization, and technology with information technology (independent variables).

\begin{tabular}{|l|l|l|}
\hline & \multicolumn{1}{|c|}{ Hypothesis } & \multicolumn{1}{|c|}{ Results } \\
\hline Hypothesis 2 (H2) & $\begin{array}{l}\text { There is a significant relationship between } \\
\text { employee performance and effectiveness } \\
\text { with organization and information } \\
\text { technology. }\end{array}$ & \\
\hline
\end{tabular}

\section{Discussion}

As such, the findings allow the researcher to conclude that the HRMIS system is vital for the functioning of any type of organization. The descriptive analysis for the human resources variable shows a value of 4.14 and standard deviation of 0.71 . This reveals that the HRMIS system is a component which is strongly tied to employee performance and effectiveness within an organization. The researcher can also conclude that the majority of employees at the studied organization feel empowered by the use of information technology. This is reflected in the highest mean value recorded from the statement "Employees at my company are empowered by the use of information technology" with the value of 3.98 respectively.

The researcher found that the technology at this organization influences employee performance and effectiveness when combined with the component of IT. The recorded mean value of 4.12 and the standard deviation of 0.67 indicates that the use of technology at this organization carries a significant impact and has an existing relationship with employee performance and effectiveness. 
The findings from this investigation on the factors which impact employee performance and effectiveness that was carried out at a local state government-based organization establish that the tested variables all have relationships with employee performance and effectiveness. These variables are the combinations of organization, technology and human resources with information technology.

The results of the research reveal that all the independent variables, namely the merging of human resources and IT, technology and IT, and organization and IT, all have a positive influence on employee performance and effectiveness, which is the dependent variable. The relationships between the independent variables and dependent variable are at a moderate level. Since the results answer the research question, it can be said that the research objectives have been fulfilled. Recommendations are needed for the reference of future researchers and practitioners, and as such they are detailed in the following section.

\section{Recommendation}

\section{Human resources department}

Based on the study findings, it is recommended that the human resources department encourage all systems in the organization to be more cooperative in efforts to manage issues which arise among the staff which are relevant to the scope of HR. The human resources department must also see to it that the IT staff at the organization is capable of creating technology which will cut down on expenses for the HR unit. The descriptive analysis results show that the lowest mean value of 3.81 and standard deviation of 0.74 is from the question "With this combination, the cost for the HR system have been reduced". This reflects the belief of the organization's employees that the construction of a solid HR framework is too expensive. The human resources department must also ensure that the system is capable of efficiently and promptly dealing with employee complaints. The HR department must always be aware and up to date with issues and problems that are brought to their attention Human resources should also work together with the IT section in order to establish a system which can oversee and observe staff activity. This can help ensure that employees are carrying out their tasks in a timely and appropriate manner, and are not slacking in their work. This can impact employee performance and effectiveness at this organization.

\section{IT Department}

It is recommended that the IT department monitor the most recent and updated technological trends before introducing or establishing them in the organization. For instance, it may be more favourable to utilize the fingerprint recognition system as opposed to the punch card system for recording attendance. IT staff must ensure that the technological systems in the organization are current and best suited to the firm's needs. For instance, the IT department should be able to guarantee that the introduction of a fingerprint recognition system will positively influence employee performance and effectiveness. A system, application or practice which has no impact on employee performance or effectiveness will be a liability, since it incurs cost on behalf of the organization but carries no tangible or sustainable effects.

\section{Organization}

It is recommended that organizations utilize information technology in the context of decision- 
making processes in the firm. Based on the findings, the lowest mean value is recorded for the question "Information technology improves the process and content of decision making in my company" with the mean value of 3.81. This indicates that most employees at this organization are of the opinion that information technology systems at their workplace are not effectively employed in the interests of facilitating decision-making processes for the organization.

\section{Future Research}

This study was carried out with certain limitations. The first was the challenge of distributing questionnaires to all staff members at the organization in question. Many employees carry out their daily tasks outside of the workplace, which presented the complication of finding and communicating with those employees. Although the researcher was able to conveniently email the entire body of staff for the purposes of the study, there were also employees who did not respond to attempts at communication. It is hoped that future research projects will utilize a larger range and scope of respondents to participate in the interests of obtaining more accurate and relevant results.

Finally, top management level staffs were not part of this study due to the challenges involved for the researcher to gain the opportunity to meet and communicate with them. The researcher makes note of this particular limitation because it is believed that the opinions and perspectives of top management personnel will differ from those of other staff members, especially when it comes to the issues of organizational practices. It is hoped that the organization's top management figures will be accessible and cooperative in future studies in order to ensure that a more in-depth and detailed study is possible.

\section{References}

Brynjolfsson, E., and Hitt, L. M. (2000). Beyond Computation: Information Technology, Organizational Transformation and Business Performance, 14, 23-48.

Gerhart, B. (1996). The Impact Of Human Resource Management On Organizational Performance : Progress And Prospects State University of New York at Buffalo. The Academy of Management Journal, 39(4), 779-801.

Litwin, A. (2011). Technological Change At Work: the Impact of Employee Involvement on the Effectiveness of Health Information Technology.

Unesco. (2002). Information and communication technology in education. Dera.loe.Ac.Uk, 148.

Um, F. D., Cowden, R., \& Karodia, A. M. (2014). the Impact of Training and Development on Employee Performance: a Case Study of Escon Consulting. Singaporean Journal of Business Economics and Management Studies, 3(3), 72-105.

UNESCO and UNESCO Institute of for Statistics and group Talal Abu-Ghazaleh. (2013). ICT in education in five Arab countries Comparative analysis of the integration of ICT and eReadiness in Schools in Egypt, Jordan, Oman, Palestine, Qatar.

Smith, J. (2008). Information Technology' s Influence on Productivity

Byrd, T. A., \& Turner, D. E. (2000). Measuring the Flexibility of Information Technology Infrastructure: Exploratory Analysis of a Construct. Journal of Management Information Systems, 17(1), 167-208. 
INTERNATIONAL JOURNAL OF ACADEMIC RESEARCH IN BUSINESS AND SOCIAL SCIENCES Vol. 9, No. 6, June, 2019, E-ISSN: 2222-6990 (C) 2019 HRMARS

Bulmash, J. (2013). Human Resources Management and Technology. Human Resources Management in Canada, 49-72.

Ahmadi, S., Keshavarzi, A., \& Foroutan, M. (2011). The application of information and communication technologies (ict) and its relationship with improvement in teaching and learning. Procedia - Social and Behavioral Sciences, 28, 475-480.

Cai, M., Wang, W., Cui, Y., \& Stanley, H. E. (2018). Multiplex network analysis of employee performance and employee social relationships. Physica A: Statistical Mechanics and Its Applications, 490, 1-12. 